\title{
Van Florasında Yayılış Gösteren Teucrium Cinsine Ait Bazı Türlerin Kimyasal İçerikleri
}

\section{Rüveyde TUNÇTÜRK ${ }^{1}$ (D), Murat TUNÇTÜRK ${ }^{1}$ (D), Tamer ERYIĞ'̇ंT2 ${ }^{\mathscr{P}}$ (D)}

${ }^{1}$ Van Yüzüncü Yıl Üniversitesi, Ziraat Fakültesi, Tarla Bitkileri Bölümü, ${ }^{2}$ Van Yüzüncü Yıl Üniversitesi, Gevaş Meslek Yüksekokulu, Bitkisel

Üretim Bölümü, Gevaş-Van, Türkiye

$\square$ : tamyigit@hotmail.com

\section{ÖZET}

Teucrium L. cinsinin yer aldığı Lamiaceae familyası, Türkiye'nin en zengin üçüncü familyası konumundadır. Teucrium'un gen merkezi Akdeniz Bölgesi olmakla birlikte dünyada hemen hemen her habitatta ve rakımda yetişen bitkilerdir. Bu çalışmada, Doğu Anadolu Bölgesi'nde yer alan Van gölü çevresinde doğal yayılış gösteren Teucrium cinsine ait 2 türün (Teucrium polium L. ve Teucrium chamaedrys L. subsp. chamaedrys) bazı besin öğeleri ve mineral madde içeriğinin tespit edilmesi amaçlanmıştır. Bitki örneklerinde toplam kül, ham protein, $\mathrm{pH}$, ham selüloz ve $\mathrm{N}, \mathrm{Na}, \mathrm{Mg}, \mathrm{K}, \mathrm{Ca}, \mathrm{P}, \mathrm{S}$, $\mathrm{Fe}, \mathrm{Zn} \mathrm{Mn}, \mathrm{Cu}, \mathrm{Cr}, \mathrm{Cd}, \mathrm{Co}, \mathrm{Pb}$ gibi bazı mineral madde içerikleri incelenmiştir.

Araştırma sonucunda elde edilen veriler incelendiğinde, kimyasal kompozisyonun türlere göre farklılık gösterdiği belirlenmiştir. $T$. polium ile T. chamaedrys subsp. chamaedrys türlerinde sirasiyla; toplam kül oranı her iki türde de \% 6.07, toplam azot içeriği \% 1.76 0.77 , protein oranı $\% 11.0-4.81, \mathrm{pH} 6.33-5.03$ ve ham selüloz oranı \% 36.83 - 37.15 olarak tespit edilmiştir. Ayrıca, Teucrium türlerinin farklı oranlarda potasyum (7.51-4.34 $\left.\mathrm{g} \mathrm{kg}^{-1}\right)$, fosfor $(4.41-1.37 \mathrm{~g} / \mathrm{kg})$, magnezyum (3.57 - $\left.1.81 \mathrm{~g} \mathrm{~kg}^{-1}\right)$, kükürt $\left(2.22-1.27 \mathrm{~g} \mathrm{~kg}^{-1}\right)$, mangan (34.71 - $\left.50.78 \mathrm{mg} \mathrm{kg}^{-1}\right)$, çinko $\left(28.41-26.22 \mathrm{mg} \mathrm{kg}^{-1}\right)$ ve demir $(255.35$ - $\left.221.22 \mathrm{mg} \mathrm{kg}^{-1}\right)$ içerdiği belirlenmiştir. Ağır metal içeriği bakımından ise, T. chamaedrys subsp. chamaedrys türünün daha fazla içeriğe sahip olduğu tespit edilmiştir.
Makale Tarihçesi

Geliş Tarihi: 05.07.2018

Kabul Tarihi: 26.11.2018

Anahtar Kelimeler
Teucrium,
mineral,
ağır metal,
Van florası

Araştırma Makalesi

\section{Chemical Contents of Some Species of Teucrium Genus Distributed in Van Flora}

\section{ABSTRACT}

Lamiaceae family, including the Teucrium genus, is Turkey's third richest family. Albeit Teucrium's gene center is the Mediterranean Territory, they grow in almost every habitat and altitude of the world. In this study, objective of this study was to determine the nutrient and mineral contents of two species (Teucrium polium L. and Teucrium chamaedrys L. subsp. chamaedrys) belonging to Teucrium genus distributed naturally in Van province in Eastern Anatolia Region. In the plant samples, total ash, crude protein, $\mathrm{pH}$, crude fiber and some mineral including $\mathrm{N}, \mathrm{Na}, \mathrm{Mg}, \mathrm{K}, \mathrm{Ca}, \mathrm{P}, \mathrm{S}, \mathrm{Fe}, \mathrm{Zn}, \mathrm{Mn}, \mathrm{Cu}, \mathrm{Cr}, \mathrm{Cd}, \mathrm{Co}$, $\mathrm{Pb}$ contents were observed.

When the data obtained were examined, it was determined that the chemical composition differs based on species. Teucrium polium and T. chamaedrys species sustained a content ratio of $1.76-0.77 \%, 11.0$ $4.81 \%, 6.33-5.03 \%, 6.07-6.07 \%$, and $36.83-37.15 \%$ for total nitrogen, protein, $\mathrm{pH}$, total ash, and fiber, respectively. In addition, it was determined that Teucrium species sustained different potassium (7.51- $\left.4.34 \mathrm{~g} \mathrm{~kg}^{-1}\right)$, phosphorus (4.41-1.37 $\left.\mathrm{g} \mathrm{kg}^{-1}\right)$, magnesium (3.57-1.81 $\left.\mathrm{g} \mathrm{kg}^{-1}\right)$, sulfur (2.22-1.27 $\left.\mathrm{g} \mathrm{kg}^{-1}\right)$, manganese (34.71-50.78 $\left.\mathrm{mg} \mathrm{kg}^{-1}\right)$, zinc (28.41-26.22 $\left.\mathrm{mg} \mathrm{kg}^{-1}\right)$ and iron $\left(255.35-221.22 \mathrm{mg} \mathrm{kg}^{-1}\right)$ ratios, respectively. In terms of heavy metal content, the highest values were obtained from T. chamaedrys subsp. chamaedrys.

\section{Article History}

Received : 05.07.2018

Accepted : 26.11.2018

\section{Keywords \\ Teucrium, mineral, heavy metal, flora of Van}

\section{Research Article}


To cite: Tunçtürk R, Tunçtürk M, Eryiğit T 2019. Van Florasında Yayılış Gösteren Teucrium Cinsine Ait Bazı Türlerin Kimyasal İçerikleri. KSÜ Tar Doğa Derg 22(1) : 138-142, DOI : 10.18016/ksutarimdoga.vi.440882.

\section{GIRISS}

Tüm dünyada olduğu gibi ülkemizde de çeşitli bitkiler yıllardan beri halk arasında çay, baharat ve tedavi amaçlı olarak kullanılmaktadır. Türkiye, ekonomik değeri yüksek bitkilerin dâhil olduğu Lamiaceae familyasının önemli gen merkezlerinden biridir. $\mathrm{Bu}$ familya ülkemizde 45 cinste yaklaşık 846 tür ile temsil edilmektedir (Kahraman ve ark., 2009). Teucrium cinsi ülkemizde ise 35 türe sahip önemli bir cinstir (Dinç ve Doğu, 2016). Bu bitkiler tek yıllık ya da çok yıllık otsu bitki ya da çalı formundadırlar (Davis, 1982; Davis ve ark., 1988; Ekim, 1982).

Teucrium cinsine ait türlerden, içerdikleri çeşitli etken maddeler nedeni ile 2000 ylldan daha uzun süredir tıbbi amaçlı bitkiler olarak yararlanılmaktadır (Davis ve ark., 1988; Ulubelen ve ark., 2000). Teucrium polium ve Teucrium chamaedrys türleri Türkiye'de oldukça geniş bir coğrafik yayılıma sahiptirler. Tıbbi bitkiler arasinda yer alan bu bitki grubunun kullanılan bitki kısımları, toprak üstü yani gövde, yaprak, çiçek ve meyvesidir. Halk tarafından; gövde, yaprak ve çiçek kısımları kaynatılıp suyu içilir. Halk arasında tıbbi olarak ishal, nefes darlığ öksürük, boğaz iltihabı, egzama, yara ve mide gibi rahatsızlıklarını iyileştirici (Baytop, 1999), idrar arttırıcı, gaz söktürücü, sinir uyarıcı, ateş düşürücü, kuvvet verici, insülin düzenleyici (Bagci ve ark., 2010), anti-romatizmal zayıflatıcı, tansiyon düşürücü gibi birçok tıbbi etkiye sahip olduğu (Bruno ve ark., 2003), yaprakları çiğ olarak çiğnendiğinde ağrıları, özellikle de karın ağrısını kısa sürede kestiği ayrıca bu bitkilerin serbest radikal giderici ve bitki ekstraktlarının da doğal antioksidan olarak kullanılabileceği ortaya konulmuştur (Kadifkova Panovska ve ark., 2005). Bu çalışmada ele alınan özellikle $T$. polium'un şeker hastalığ 1 , romatolojik hastalıklar, inflamasyon ve gastrointestinal bozukluklar gibi farklı hastalıklar için kullanıldığı, antioksidan etkiye sahip olduğu (Rafieian-Kopaei ve ark., 2014) ve T. chamaedrysin ise toprak üstü aksamlarının, yüzyıllar boyunca ağrı kesici, sıkılaştırıcı, sindirim sistemi, antispazmodik ve antiinflamatuar ajanlar olarak kullanıldığı ve farmakolojik etkileri nedeniyle, bu bitki yaygın olarak geleneksel tıpta, sindirim bozuklukları, öksürük, astım, apse, konjunktivit ve selülit tedavisinde kullanıldığı rapor edilmiştir (Vlase ve ark., 2014). Doğu Anadolu bölgesinde uzun zamandan beri diyabet tedavisinde çeşitli şifalı bitkileri kullanmıştır. Antidiyabetik preparatlar, bölgedeki geleneksel ilaçlara değerli alternatif ve / veya tamamlayıcı ajanlar olarak kullanılmıştır. Van, Bitlis ve Hakkari illerinde Teucrium türleri genelde bu amaçla kullanılan önemli bitkiler arasında yer almaktadır (Dalar, 2018).

Bitkiler içinde doğal olarak bulunan $(\mathrm{Ca}, \mathrm{Mg}$ ve $\mathrm{Na})$ insan ve hayvan sağllğı için gerekli olan metallerin yanı sıra çok gerekli olmasına rağmen, bazı ağır metaller $(\mathrm{Cu}, \mathrm{Zn}, \mathrm{Pb}, \mathrm{Cd}$ vb.) organizma için esansiyel olup bunların yokluğunda hem büyüme hem de üreme durmaktadır (Bat ve ark., 1999). Bitkilerde $\mathrm{Cr}, \mathrm{Pb}, \mathrm{Cd}$, $\mathrm{Co}, \mathrm{Hg}$ ve $\mathrm{Ni}$ gibi elementler belirli seviyelere ulaştıklarında zehir etkisi gösteren bazı metallerin de bulunduğu görülmektedir (Gökkuş ve ark., 2013; Özcan, 2004).

Toksik metallerin, kontamine olmuş topraklarda yapılan bitkisel üretimlerde ve doğal alanların kirlenmesi ile gıda zincirine dâhil olduğu, tüm canlı sistemlerini etkilediği gibi insan sağllğında da olumsuzluklara neden olduğu bilinmektedir (Çağlarırmak ve Hepçimen, 2010). Örneğin; kurşunun vücutta $\% 5$ oranında olan absorbsiyonu kalsiyum ve demir gibi birçok mineralin vücut tarafından emilimini azaltmaktadır. İyonik çap ve yük benzerlikleri nedeniyle, kurşun kalsiyumun yerine geçebilmekte ve kemik dokusuna yerleşebilmektedir. Yüksek miktarlarda kalsiyum alındığında kemik dokusuna yerleşip bağlanmış olan kurşun kalsiyumla yer değiştirebilmektedir (Bilgiç Alkaya ve ark., 2015). Böylece serbest kalan kurşun böbrek, sinir sistemi ve yüksek tansiyon gibi rahatsızlıklara neden olmaktadır (Baş ve Demet, 1992; Topçuoğlu, 2014).

$\mathrm{Bu}$ çalışmada; Van florasında doğal olarak yayılış gösteren bazı Teucrium türlerinin içermiş olduğu bazı besin elementleri ve ağır metal içeriklerinin belirlenmesi amaçlanmıştır.

\section{MATERYAL ve METOT}

2013 yılında, Doğu Anadolu Bölgesi’nde yer alan Van Gölü çevresinde florada doğal olarak yayılış gösteren iki Teucrium türü (Teucrium polium ve Teucrium chamaedrys subsp. chamaedrys) doğal yayılış alanından toplanarak, Yüzüncü Yıl Üniversitesi Fen Fakültesi, Biyoloji Bölümü'nde Flora of Turkey'den (Davis, 1982) faydalanılarak teşhisleri yapılmıştır (Çizelge 1).

Toplanan bitkilerin toprak üstü kısımları de-iyonize su ile yıkanarak oda sıcaklığında kurutulmuştur. Kurutma işleminden sonra bitki örneklerinin öğütme işlemi gerçekleştirilmiştir. Kül oranı (\%); öğütülmüş bitki örneklerinden $3 \mathrm{~g}$ alınıp porselen krozeler içerisinde üzerine $1 \mathrm{ml}$ alkol eklenerek kül firınında $550{ }^{\circ} \mathrm{C}$ 'de rengi beyaz ya da açık gri renk olana kadar yakılarak kül oranı tespit edilmiştir (Elgün ve ark., 1998). Azot oranı, Kjheldahl yöntemi ile \% olarak belirlenmiş ve elde edilen değerler 6.25 katsayısı ile çarpılarak ham protein oranı belirlenmiştir. 
Çizelge 1. Van gölü çevresinde yayılış gösteren iki Teucrium türünün bazı özellikleri

\begin{tabular}{|c|c|c|c|c|c|c|}
\hline Bilimsel adı & Familya & Yerel adı & $\begin{array}{l}\text { Kullanılan } \\
\text { kısmı }\end{array}$ & $\begin{array}{l}\text { Kullanılma } \\
\text { şekli }\end{array}$ & $\begin{array}{l}\text { Toplandiğ1 } \\
\text { Bölge }\end{array}$ & $\begin{array}{l}\text { Kol. } \\
\text { Numarası }\end{array}$ \\
\hline Teucrium polium & Lamiaceae & $\begin{array}{l}\text { Mayasıl otu, } \\
\text { tüylü kısamahmut }\end{array}$ & $\begin{array}{l}\text { Toprak üstü } \\
\text { aksamı }\end{array}$ & Çay, gıda & $\mathrm{B} 1$ & M2102 \\
\hline $\begin{array}{l}\text { Teucrium chamaedrys L. } \\
\text { subsp. chamaedrys }\end{array}$ & Lamiaceae & $\begin{array}{l}\text { Dalak otu, } \\
\text { mayasıl otu }\end{array}$ & $\begin{array}{l}\text { Toprak üstü } \\
\text { aksamı }\end{array}$ & Çay, gida & B2 & F3841 \\
\hline
\end{tabular}

B1: B9 Van: Muradiye, Şelale kenarları ve iç kısımlar, step, 1800 m, 39º 03' 14.02" K - 430 45' 30.19" D

B2: B9 Van: Özalp, Yünkuşak köyü, Radar çevresi, step, 2050 m, 38 38' 29.05" K - 44 03' 20.32" D

Bitki örneklerinin, ham selüloz tayini AOAC (2000) metodu ile tespit edilmiştir. Bitki materyallerinin mineral içeriklerini belirlemek amacıyla Atomik Absorpsiyon Spektrometre (AAS) cihazı kullanılmıştır (Hanlon, 1992). Fosfor içeriği molybdate-vanadate metoduna göre, kükürt içeriği ise (Mitchell, 1992) tarafindan rapor edilen yönteme göre UVSpektrofotometre (Shimadzu UV-1201 V; Shimadzu, Kyoto, Japan) ile tespit edilmiştir. Çalışmada yürütülen bütün analizler üçer tekerrür halinde yapılarak standart sapmaları tespit edilmiştir.

\section{BULGULAR ve TARTIŞMA}

$T$. polium ve $T$. chamaedrys subsp. chamaedrys türlerinin bazı besin ve mineral içeriklerine ait ortalamamalar ve standart sapma değerleri Çizelge 2 ve Çizelge 3’te verilmiştir.

Çalışma sonucunda; toplam kül miktarı her iki Teucrium türlerinde aynı değerde (\%6.07) tespit edilmiştir. Azot içeriği (\%1.76), protein oranı (\%11) ve pH değeri (6.33) bakımından ise en yüksek değerler $T$. polium türünden, en düşük değerler ise sırasıyla;

$\% 0.77, \% 4.81$ ve $\% 5.03$ olarak T. chamaedrys subsp. chamaedrys türünde tespit edilmiştir. En fazla ham selüloz oranı \%37.15 ile T. chamaedrys subsp. chamaedrys türünde tespit edilmiştir (Çizelge 2).

Konu ile ilgili yapılan çalışmalarda; Juan ve ark. (2004) T. chamaedrys türünde protein oranını \%21.1, Bakoğlu ve ark. (1999) T. polium'de protein oranını \% 13.30-21.79, selüloz oranını \% 11.05-25.64 arasında, Yücel ve ark. (2011) aynı bitki türünde protein oranını \% 2.23-5.92 ve Hilooğlu ve ark. (2017) ise $T$. leucophyllum Montb. \& Aucher ex Benth. türünde azot oranını \%1.23 olarak tespit etmişlerdir.

Çalışmadan elde edilen bulgular farklı doğal ekolojilerde yapılan araştırma bulguları ile kısmen benzerlik göstermektedir. Ekolojik faktörlerin diğer kültür bitkilerine oranla tıbbi bitkilerde etkisinin özellikle bitkinin kimyasal kompozisyonu üzerinde çok daha fazla olduğu bilinmektedir. Tıbbi bitkilerde verim kadar kalite de önemlidir, hatta belirli kalitenin altında olanlar çok verimli olsalar dahi yetiştirilmezler (Şahin, 2013). Bu çalışmada en fazla $\mathrm{Na}\left(0.46 \mathrm{~g} \mathrm{~kg}^{-1}\right)$, $\mathrm{Mg}\left(3.57 \mathrm{~g} \mathrm{~kg}^{-1}\right)$ ve $\mathrm{Ca}\left(13.27 \mathrm{~g} \mathrm{~kg}^{-1}\right)$ içeriği $T$. chamaedrys subsp. chamaedrys türünde tespit edilirken, en fazla $\mathrm{K}\left(7.51 \mathrm{~g} \mathrm{~kg}^{-1}\right), \mathrm{P}\left(4.41 \mathrm{~g} \mathrm{~kg}^{-1}\right)$ ve $\mathrm{S}$ içeriği $2.22 \mathrm{~g} \mathrm{~kg}^{-1}$ olarak $T$. polium türünde tespit edilmiştir (Çizelge 3).

Yücel ve ark. (2011), T. polium türünde $\mathrm{Na}$ oranını $\% 0.47$, P oranını \%0.66, Hilooğlu ve ark. (2017) $T$. leucophyllum türünde $\mathrm{K}$ oranını $7.06 \mathrm{~g} \mathrm{~kg}^{-1}, \mathrm{Mg}$ oranını $1.73 \mathrm{~g} \mathrm{~kg}{ }^{-1} \mathrm{ve} \mathrm{P}$ miktarını $0.73 \mathrm{~g} \mathrm{~kg}^{-1}$ olarak tespit etmişlerdir. Tespit edilen bu farklılıkların sebebi olarak bu türlerden saptanan varyasyon ile önceki çalışma sonuçları arasındaki farklılıkların çeşitli büyüme koşullarından, genetik faktörlerden, toprak verimliliğinden, mineral alımının verimliliğinden ve kullanılan analiz prosedürlerinden kaynaklandığı söylenebilir (Özcan ve ark., 1998). Çizelge 3’te görüldüğü üzere çalışmada, Teucrium türleri arasında en fazla $\mathrm{Zn}$ içeriği $28.41 \mathrm{mg} / \mathrm{kg}$ ve Fe içeriği $(255 \mathrm{mg} \mathrm{kg}$ 1) T. polium türünden tespit edilmiştir. Hilooğlu ve ark. (2017), T. leucophyllum türünde $\mathrm{Zn}$ oranını $17.39 \mathrm{mg} \mathrm{kg}^{-1}$ ve Fe oranını $704.50 \mathrm{mg} \mathrm{kg}^{-1}$ olarak tespit edilmiştir.

İnsan vücudunda çok az miktarda bulunan ve çeşitli metabolik süreçleri kolaylaştıran bir koenzim olarak görev yapan $\mathrm{Mn}$ besin elementinin bu çalışma sonucuna göre; belirlenen değerleri incelendiğinde iki tür arasında oldukça yüksek bir farklılığın olduğu ve en fazla $\mathrm{Mn}$ içeriğinin $\left(50.78 \mathrm{mg} \mathrm{kg}^{-1}\right)$ T. chamaedrys subsp. chamaedrys türünde bulunduğu belirlenmiştir (Çizelge 3). Hilooğlu ve ark. (2017), T. leucophyllum türünde $\mathrm{Mn}$ oranını $32.24 \mathrm{mg} \mathrm{kg}^{-1}$, Pavlova ve Karadjova (2013), T. chamaedrys türünde Mn içeriğini $35 \mathrm{mg} \mathrm{kg}^{-1}$ ve $\mathrm{Zn}$ içeriğini $24 \mathrm{mg} \mathrm{kg}^{-1}$ olarak tespit etmişlerdir.

Çizelge 2. Teucrium türlerinin bazı besin içeriği ortalama değerleri $\pm \mathrm{Sd}$

\begin{tabular}{lrc}
\hline İncelenen Parametreler & Teucrium polium & Teucrium chamaedrys subsp. chamaedrys \\
\hline Toplam kül (\%) & $6.07 \pm 0.115$ & $6.07 \pm 0.115$ \\
Azot (\%) & $1.76 \pm 0.050$ & $0.77 \pm 0.012$ \\
Ham protein (\%) & $11.0 \pm 0.315$ & $4.81 \pm 0.067$ \\
pH & $6.33 \pm 0.006$ & $5.03 \pm 0.058$ \\
Ham selüloz (\%) & $36.83 \pm 0.153$ & $37.15 \pm 0.150$ \\
\hline
\end{tabular}


Cizelge 3. Teucrium türlerinin mineral ve bazı ağır metal kompozisyonu ortalama değerleri $\pm \mathrm{Sd}$

\begin{tabular}{|c|c|c|}
\hline Mineraller ve ağır metaller & Teucrium polium & Teucrium chamaedrys subsp. chamaedrys \\
\hline Sodyum $(\mathrm{Na})(\mathrm{g} \mathrm{kg}-1)$ & $0.44 \pm 0.006$ & $0.46 \pm 0.007$ \\
\hline Magnezyum (Mg) (g kg-1) & $1.81 \pm 0.162$ & $3.57 \pm 0.285$ \\
\hline Potasyum (K) (g kg-1) & $7.51 \pm 0.532$ & $4.34 \pm 0.334$ \\
\hline Kalsiyum (Ca) (g kg-1) & $10.10 \pm 0.327$ & $13.27 \pm 0.037$ \\
\hline Fosfor $(\mathrm{P})\left(\mathrm{g} \mathrm{kg}^{-1}\right)$ & $4.41 \pm 0.255$ & $1.37 \pm 0.085$ \\
\hline Kükürt (S) (g kg-1) & $2.22 \pm 0.175$ & $1.27 \pm 0.017$ \\
\hline Çinko (Zn) (mg kg-1) & $28.41 \pm 1.070$ & $26.22 \pm 0.986$ \\
\hline Demir (Fe) (mg kg-1) & $255.35 \pm 25.889$ & $221.22 \pm 18.707$ \\
\hline Mangan (Mn) (mg kg-1) & $34.71 \pm 0.516$ & $50.78 \pm 2.184$ \\
\hline Bakır $(\mathrm{Cu})(\mathrm{mg} \mathrm{kg}-1)$ & $16.19 \pm 1.278$ & $16.64 \pm 0.698$ \\
\hline Krom (Cr) (mg kg-1) & $0.51 \pm 0.098$ & $0.26 \pm 0.021$ \\
\hline Kobalt (Co) (mg kg-1) & $0.20 \pm 0.062$ & $1.71 \pm 0.240$ \\
\hline Kadmiyum (Cd) (mg kg-1) & $0.09 \pm 0.006$ & $0.38 \pm 0.450$ \\
\hline $\operatorname{Kurşun~}(\mathrm{Pb})(\mathrm{mg} \mathrm{kg}-1)$ & $0.04 \pm 0.003$ & $0.32 \pm 0.036$ \\
\hline
\end{tabular}

Araştırma sonuçlarına göre; her iki Teucrium türünde de $\mathrm{Cu}$ içeriği arasında önemli bir farklılı̆̆ın olmadığı değerlerin birbirine çok yakın olduğu belirlenirken, en fazla $\mathrm{Cu}$ içeriği $16.64 \mathrm{mg} \mathrm{kg}^{-1}$ olarak $T$. chamaedrys subsp. chamaedrys türünde tespit edilmiştir (Çizelge 3). Pavlova ve Karadjova (2013), T. chamaedrys türünde $\mathrm{Cu}$ içeriğini $7.6 \mathrm{mg} \mathrm{kg-1}$, Hilooğlu ve ark. (2017), Teucrium leucophyllum türünde $\mathrm{Cu}$ içeriğini 9.38 ppm olarak tespit etmişlerdir. Cu özellikle protein sentezlenmesinde ve enerji üretiminde rol oynayan önemli bir element olarak bilinmektedir.

Çalışmada en fazla Co (1.71 $\left.\mathrm{mg} \mathrm{kg}^{-1}\right)$, Cd (0.38mg kg-1) ve $\mathrm{Pb}\left(0.32 \mathrm{mg} \mathrm{kg}^{-1}\right)$ içeriği $T$. chamaedrys subsp. chamaedrys türünden tespit edilirken, en yüksek $\mathrm{Cr}$ içeriği (0.51 mg kg-1) T. polium'dan elde edilmiştir (Çizelge 3). Pavlova ve Karadjova (2013) $T$. chamaedrys türünde yaptığı çalışmada, Co $\left(9.4 \mathrm{mg} \mathrm{kg}{ }^{-}\right.$ 1), $\mathrm{Cd}$ (1.43mg $\left.\mathrm{kg}^{-1}\right)$ ve $\mathrm{Pb}\left(1.4 \mathrm{mg} \mathrm{kg} \mathrm{kg}^{-1}\right.$ oranını çalışmamızdan daha yüksek miktarda tespit etmişlerdir. Farklı tür ve çeşitlerin genetik yapılarının çeşitliliğinden dolayı iklim ve çevre koşullarına farklı tepkilerinden kaynaklı olarak bu bitkilerin kimyasal kompozisyonlarında farklılık meydana geldiği söylenebilir.

Ağır metaller belli limitlerin üzerinde vücuda alındığında toksisiteye neden olmaktadır. Özellikle de $\mathrm{Pb}$ ve $\mathrm{Cd}$ çok az dozlarda bile organizmalarda toksisiteye neden olduğundan sağlık sorunlarına yol açabilmektedir. Bu nedenle toksik etki gösteren ağır metallerin gıdalardaki miktarı belli limitlerle sınırlandırıldığı bildirilmiştir (Yazkan ve ark., 2002).

\section{SONUÇ}

Yeryüzünde geniş bir doğal yayılış alanına sahip ve özellikle de bitkisel ilaç olarak da çok fazla tüketimi yapılan Teucrium türlerinin, ülkemizde de tıbbi etkilerinden dolayı kullanımı oldukça yaygındır. Ülkemiz tarımsal potansiyel olarak, coğrafi konumu, iklimi ve doğal floranın zenginliği bakımından dünya tıbbi ve aromatik bitkiler ticaretinde lider ülkeler arasında yer almaktadır. Tıbbi amaçla kullanılan bitkilerin birçoğu doğadan toplanarak pazarlanmaktadır. Toplanan bu bitkilerin insan sağlığına etkileri araştırılmalı, kullanımlarına dikkat edilmeli ve bilinçli olarak tüketilmeleri sağlanmalıdır. Van ve çevresinde, floradan toplamak suretiyle doğal yayılış gösteren mevcut türler üzerinde yaptığımız araştırma sonucunda; en fazla azot, protein, K, P, S ve Fe içeren türün T. polium ve en fazla ağır metal içeren türün ise T. chamaedrys subsp. chamaedrys türünün olduğu belirlenmiş, fakat $\mathrm{Mn}, \mathrm{Cu}, \mathrm{Cr}, \mathrm{Co}, \mathrm{Cd}$ ve $\mathrm{Pb}$ gibi zehirli elementlerin incelenen bu iki bitki türündeki seviyeleri Gökkuş ve ark. (2013) bildirdiği değerlere paralel olduğu gerek bitki gerekse hayvan beslenmesi açısından herhangi bir zarar oluşturacak boyutta olmadığı ve aynı zamanda Dünya Sağlık Örgütü (WHO, 1996) tarafından bildirilen referans aralığında kaldığından insan sağlığı üzerine de zararlı miktarda olmadığı tespit edilmiştir.

Sonuç olarak gerek doğrudan tüketilen ve gerekse birçok hastalığın tedavisinde kullanılan tıbbi bitkilerin analizlerinin yapılarak içeriğinin tespit edilmesi, bilinçli olarak tüketilmesi ve alternatif tıpta kullanılması yaşanabilecek tehlikeli sonuçları engelleyecektir. Bu nedenle, yapılan bu çalışma, bitki çeşitliliği bakımından zengin olan ülkemizde, küresel hastalıkların ve kıtlığın giderek arttığı dünyamızda oldukça fazla tüketilen bitkilerin yöresel tüketim şekillerinin, besin içeriğinin ve tıbbi olarak kullanımlarının belirlenmesine yönelik yapılacak ayrıntılı çalışmalara ışık tutacaktır.

\section{KAYNAKLAR}

AOAC 2000. (17. Edition) Official methods of analysis, 17 ed. Association of Official Analytical Chemists, Inc, Maryland, USA.

Bagci E, Yazgin A, Hayta S, Cakılcioglu U 2010. Composition of the essential oil of Teucrium chamaedrys L.(Lamiaceae) from Turkey. Journal of Medicinal Plants Research, 4(23): 2588-2590.

Bakoğlu A, Koç A, Gökkuş A 1999. Dominant mera bitkilerinin biomas ve kimyasal kompozisyonlarının büyüme dönemindeki değişimi II. kimyasal kompozisyondaki değişimler. Turkish 
Journal of Agriculture and Forestry, 23(2): 495508.

Baş L, Demet Ö 1992. Çevresel toksikoloji yönünden bazı ağır metaller. Çevre Dergisi, 5: 42-46.

Bat L, Çulha M, Öztürk M 1999. Ağır Metaller. Süleyman Demirel Üniversitesi, Eğirdir $\mathrm{Su}$ Ürünleri Fak Dergisi, 6:166-175.

Baytop T 1999. Turkiye'de BitkilerleTedavi. Nobel Tip Kitapevi, Istanbul.

Bilgiç Alkaya D, Karaderi S, Erdoğan G, Kurt Cücü A 2015. İstanbul Aktarlarinda Satilan Bitkisel Çaylarda Ağır Metal Tayini. Marmara Pharmaceutical Journal, 19(2): 136-140.

Bruno M, Maggio AM, Piozzi F, Puech S, Rosselli S, Simmonds MS 2003. Neoclerodane diterpenoids from Teucrium polium subsp. polium and their antifeedant activity. Biochemical systematics and ecology, 31(9): 1051-1056.

Çağlarırmak N, Hepçimen AZ 2010. Ağır metal toprak kirliliğinin gıda zinciri ve insan sağlığına etkisi. Akademik Gida, 8(2): 31-35.

Dalar A 2018. Plant Taxa Used in the Treatment of Diabetes in Van Province, Turkey. International Journal of Secondary Metabolite, 5(3): 171-185.

Davis PH 1982. Flora of Turkey and the East Aegean islands. Vol 7. Edinburgh University Press, Edinburgh.

Davis PH, Mill R, Tan K 1988. Flora of Turkey and the East Aegean Islands. Edinburgh University Press, Edinburgh, U.K.

Dinç M, Doğu S 2016. Teucrium pruinosum var. aksarayense var. nov.(Lamiaceae) from Central Anatolia, Turkey. Modern Phytomorphology, 9:1317.

Ekim T 1982. Teucrium L. Flora of Turkey and the East Aegean islands, 753-75.

Elgün A, Ertugay Z, Certel M, Kotancılar H 1998. Tahıl ve Ürünlerinde Analitik Kalite Kontrolü ve Laboratuvar Uygulama Kılavuzu. A. Ü. Z. F., Yayın No: 67, Erzurum, sayfa: 238.

Gökkuş A, Parlak AÖ, Baytekİn H, Hakyemez BH 2013. Akdeniz Kuşağı (Çalılı Meralarında Otsu Türlerin Mineral İçeriklerinin Değişimi. Tekirdag Ziraat Fakültesi Dergisi, 10(1): 1-10.

Hanlon EA 1992. Plant Analysis Reference Procedures for the Southern Region of the United States. Southern Cooperative Series Bulletin no: 368. The University of Georgia Crops and Soil Science Dept., Athens GA.

Hilooğlu M, Yücel E, Kandemir A, Sözen E 2017. Endemik Teucrium leucophyllum Montbret \& Aucher ex Bentham.(Lamiaceae) Türünün ToprakBitki İlişkisi. KSÜ Doğa Bilimleri Dergisi, 20(2): 95-102.

Juan R, Pastor J, Millan F, Alaiz M, Vioque J 2004. Amino acids composition of teucrium nutlet proteins and their systematic significance. Annals of Botany, 94(4): 615-621.
Kadifkova Panovska T, Kulevanova S, Stefova M 2005. In vitro antioxidant activity of some Teucrium species (Lamiaceae). Acta Pharm, 55(2): 207-214.

Kahraman A, Celep F, Dogan M 2009. Morphology, anatomy and palynology of Salvia indica L.(Labiatae). World Applied Sciences Journal, 6(2): 289-296.

Mitchell CC 1992. Plant Analysis Reference Procedures for the Southern Region of the United States. Southern Cooperative Series Bulletin no: 368. The University of Georgia Crops and Soil Science Dept., Athens GA.

Özcan M 2004. Mineral contents of some plants used as condiments in Turkey. Food Chemistry, 84(3): 437-440.

Özcan M, Akgül A, Bağcı Y, Dural H 1998. Chemical composition and mineral contents of edible wild plants consumed in İçel (Mersin). SU Sci. J. 15:7277.

Pavlova D, Karadjova I 2013. Toxic element profiles in selected medicinal plants growing on serpentines in Bulgaria. Biol Trace Elem Res, 156(1-3): 288-297.

Rafieian-Kopaei M, Nasri H, Baradaran A 2014. Teucrium polium: Liver and kidney effects. Journal of Research in Medical Sciences, 19(5): 478-479.

Şahin B 2013. Farklı ekim zamanlarında yetiştirilen bazı tıbbi bitkilerin verim ve kalite özelliklerinin belirlenmesi. Selçuk Üniversitesi Fen Bilimleri Enstitüsü. Tarla Bitkileri Ana Bilim Dalı 143 sy.

Topçuoğlu B 2014. Kentsel Katı Atık Kompostu ve Arıtma Çamurunda Ağır Metallerin Bitkiler ve Çevre Üzerinde Potansiyel Etkileri ve Kirletici Limitler. Derim, 19(2): 38-49.

Ulubelen A, Topu G, Sönmez U 2000. Chemical and biological evaluation of genus Teucrium, Studies in Natural Products Chemistry. Elsevier, pp. 591-648.

Vlase L, Benedec D, Hanganu D, Damian G, Csillag I, Sevastre B, Mot AC, Silaghi-Dumitrescu R, Tilea I 2014. Evaluation of antioxidant and antimicrobial activities and phenolic profile for Hyssopus officinalis, Ocimum basilicum and Teucrium chamaedrys. Molecules (Basel, Switzerland), 19(5): 5490-5507.

WHO 1996. Trace Elements in Human Nutrition and Health. World Health Organization, Geneva.

Yazkan M, Özdemir F, Gölükcü M 2002. Cu, Zn, Pb and $\mathrm{Cd}$ content in some fish species caught in the Gulf of Antalya. Turkish Journal of Veterinary and Animal Sciences, 26(6): 1309-1313.

Yücel E, Tapirdamaz A, Yücel Senguen İ, Yılmaz G, Ak A 2011. Determining the usage ways and nutrient contents of some wild plants around Kisecik Town(Karaman/Turkey). Biological Diversity and Conservation, 4(3): 71-82. 